\title{
Factors Affecting Practical Knowledge Acquisition of Pre-service Computer Science Teachers During the Practicum: A Multiple Regression Analysis
}

\author{
Song Pu, Nor Aniza Ahmad* and Mas Nida Md. Khambari \\ Faculty of Educational Studies, Universiti Putra Malaysia \\ Selangor, Malaysia \\ Ng Keng Yap \\ Faculty of Computer Science and Information Technology, \\ Universiti Putra Malaysia \\ Selangor, Malaysia
}

\begin{abstract}
This study aimed to examine and analyze the relationship between five factors in the practicum setting and six components of practical knowledge acquisition among pre-service computer science teachers. A total of 219 Chinese pre-service computer science teachers were invited to attend this study. The method of data analysis was using multiple regression analysis. The results can be summed as follows: (a) The factor of knowledge preparation, which has strong practicality in practicum, significantly predicted the five components of practical knowledge acquisition; (b) Teaching reflection factor as a meta-cognitive and a characteristic of higher-order thinking significantly predicted the three components of practical knowledge acquisition; (c) Instructional design factor as a process of systematic reflection significantly predicted the three components of practical knowledge acquisition; (d) Both teaching practice and teamwork factor significantly predicted the two components of practical knowledge acquisition. We also suggested that teacher educators should focus on the integration of theoretical knowledge and practical knowledge by considering the effects of the five factors.
\end{abstract}

Keywords: pre-service computer science teachers; practical knowledge; teachers practicum

"Corresponding author: Nor Aniza Ahmad, email: nor_aniza@upm.edu.my 


\section{Introduction}

The practicum represents an integral part of pre-service teacher training and a process by which teachers acquire skills and knowledge from the school environment. Especially for pre-service teachers in the field of computer science education, which is highly relevant to various hands-on activities carried out in schools (Brandes, \& Armoni, 2019; Hausswolff, 2017). It should be noted that the distinctive feature of the practicum in computer science or other laboratory subjects is a formative period where practical knowledge, skills, and competencies are developed to use in practical work (Armoni, 2011; Abrahams \& Millar, 2008). Moreover, in the practicum, the identity of pre-service teachers is unique. They are not only being educated as students in universities but also educate others as teachers during practicum (Britzman, 2003). Although identity increases the complexity of pre-service teachers' practicum, many studies viewed it as an essential source of teacher knowledge acquisition (Fan, 2014).

Over the past 20 years, many previous studies on pre-service teachers' practicum have been published, including many topics in various fields. Studies have highlighted diverse viewpoints on the effectiveness of web-based teaching practicum model on pre-service teachers' performance (Lee, \& Chang, 2000), the role of practicum in computer science teachers preparation (Hazzan, \& Lapidot, 2004), the development and implementation of computer science training module (Ragonis, \& Osterlevinz, 2011; So, Hung, \& Yip, 2008), partnerships between schools and universities in the training of pre-service teachers (Chittleborough, Clarke, \& Hubber, 2010), and the virtual learning community in teachers' practicum (Gronn, Romeo, Mcnamara, \& Teo, 2013).

However, limited studies have focused on the topic of practical knowledge acquisition of pre-service teachers in practicum. This study aimed to investigate the relationship between different factors in practicum setting and practical knowledge acquisition among pre-service computer science teachers. The finding of this study can provide an overall understanding of how pre-service computer science teachers acquire practical knowledge with their practicum, which is helpful in constructing an active channel for the pre-service teachers' training in university.

\section{Theoretical Framework}

In this section, the previous studies on the practical knowledge acquisition among pre-service teachers with their practicum in computer science education were reviewed to establish the theoretical framework of practical knowledge and possible factors in a practicum that affects practical knowledge acquisition.

\subsection{Pre-service teachers' practical knowledge with their practicum}

Practical knowledge was considered as an integrated set of practical wisdom, knowledge, conceptions, beliefs, and insights that underlie teachers' actions in practice (Elbaz, 1981; Driel, Beijaard \& Verloop, 2001). Teachers' practical knowledge is cultivated out of practice, circumstances, and actions, and helps teachers to focus on their thoughts and decision making; thus, enabling them to 
understand their work (Elbaz, 1981; Shulman, 1987). Furthermore, practical knowledge is guided by practice as it is the strategic cognitive system of an individual (Pu, \& Xiang, 2017). For pre-service computer science teachers, practical knowledge is a reconstruction and assembling of knowledge from their prior knowledge and experiences, which they used as a guide to plan and enact future teaching activities.

Many suggested that practical knowledge acquisition is an integral part of pre-service computer science teachers' practicum because it overcomes the traditional dichotomy between theoretical and practical using two approaches (Smith, \& Ragan, 1999). On the one hand, theory use can be observed by the degree of how the teachers used theoretical concepts meaningfully and on the other hand, theory use can be observed in the way teachers reflected on the practical process (Oonk, Verloop, \& Gravemeijer, 2015). Practical knowledge has four essential advantages in pre-service teachers' practicum. Firstly, practical knowledge is mostly undocumented, but it is necessary for pre-service teachers' teaching practice as it meets the need for immediate actionable action (Zanting, Verloop, \& Vermunt, 2001; Carter, 1990). Additionally, not only pre-service teachers' are the applicators and disseminators of knowledge, but they are also the creators who create their own personal practical knowledge of teaching (Ben-Peretz, 2011).

Furthermore, practical knowledge helps to improve pre-service teachers' interest in developing new skills and learning styles (Oss, 2018). Last but not least, practical knowledge will develop into professional knowledge and this will enable pre-service teachers to adapt to different educational contexts (Oss, 2018, Pu, \& Xiang, 2017). Hence, practical knowledge has been presumed to be one of the central themes in pre-service teachers' practicum. Thus, practical knowledge is a necessary condition in the investigation of the process of pre-service teachers' education reformation (Driel, Beijaard, \& Verloop, 2001).

There are various connotations regarding the components and classifications of practical knowledge in the teachers' education field. Elbaz (1981) conducted research and pointed out that practical knowledge can be classified into five categories, which include: knowledge of curriculum, knowledge of subject matter, instruction knowledge, knowledge of self and knowledge of milieu. Elbaz believed that it relates these five kinds of knowledge to each other, and they are formed by the interaction of theoretical knowledge and practice. Elbaz's research on teachers' practical knowledge greatly influences other scholars' researches. The components of teachers' practical knowledge on subject teaching developed by Verloop et al. (2001) are similar to Elbaz's research. Moreover, Shulman (1987) had identified that teachers should possess several categories of knowledge, namely: (a) knowledge of educational aims, (b) knowledge of other content, (c) knowledge of learners, (d) content knowledge, and (e) general pedagogical knowledge.

Chen (2003) carried out research based on the practical knowledge theory of Elbaz and Shulman and ascertained six components model connected to practical 
knowledge in teachers' education and practicum. The six components of practical knowledge ascertained by Chen include educational beliefs, self-knowledge, situational knowledge, interpersonal relationship knowledge, teaching strategies knowledge and self-reflection knowledge (Chen, 2003; 2019). Chen's model provides a specific category of practical knowledge for teacher education and makes the concept of practical knowledge easy to apply to scientific research. Therefore, various empirical studies use this model to develop theoretical frameworks for, such as Xiaomin (2010), Lifang(2014), and Yubin, Xiaotang, Lilan, \& Linlin (2011). When applying the model to this study, the six components need to be modified to accommodate to the area of pre-service computer science teachers' practicum: (a) educational beliefs refer to teachers' understanding about the purposes of education, why teachers should participate in practicum, what kind of education students should receive, and the teaching method they would like to use; (b) self-knowledge mainly refer to teachers know about the mental representation of themselves, which contain self-teaching efficacy, self-regulation, and self-characteristics (interest, attitude, temperament, ability); (c) situational knowledge as teachers' practical pedagogical wisdom acquired through authentic practices or teachers' perceptions and understandings embedded in computer science teaching; (d) interpersonal relationship knowledge includes their perception and understanding of students, enthusiasm and passion; (e) teaching strategies knowledge refer to teachers apply subject matter knowledge, pedagogy and educational theory to specific strategies in teaching, which including the understanding of teaching objectives, the selection of teaching content and methods, the planning and implementation of educational activities, and handling of special cases; ( $\mathrm{f}$ ) self-reflection knowledge is a practice-oriented reflection, which mainly involved in before, during and after the practicum of computer science education.

\subsection{Possible factors in practicum affect practical knowledge acquisition}

When realizing that practical knowledge is an important field of teachers' knowledge, many researchers have been thinking about what factors affect teachers' practical knowledge acquisition. According to Meijer, Verloop, \& Beijaard (1999), practical knowledge is thought to be generated and constructed through (a) personal experience; (b) frequency and nature of reflection; (c) prior education; (d) personal characteristics; (e) disciplinary background; (f) the school context. Similarly, Abdelhafez (2010) found that a variety of sources that shaped the teachers' practical knowledge including (a) experience, (b) teacher practice, (c) university study in the subject department, (d) student and peer feedback, (e) expert advice. Specifically, Kauchak and Eggen (2003) argued that teacher understanding of the subject matter and experience have proved to be influential factors influencing their practical knowledge. Zanting et al. (2000) believed that teachers could develop their practical knowledge by school teaching context, teaching experience and biographies (teachers' prior education, family lives and hopes).

In order to find out the factors that affect practical knowledge acquisition among pre-service teachers in the practicum of computer science education, this study established a comprehensive framework to accommodate to different factors. 
Armoni (2011) constructed a conceptual framework for the knowledge acquisition of computer science teacher that was integrating theoretical knowledge and practical activities. Theoretical knowledge should include both social and psychological foundations so that teachers are familiar with these areas and will be able to use them in a broader context (Pietig, 1997). Additionally, teachers' education should include practical activities. Jaworski \& Gellert (2003) asserted that the theory could work in two ways. First, it is served as a mirror in the process of reflection on practice. Second, from practice, teachers can get inspiration and experience from their reflection on theory. According to this conceptual framework, computer science teachers' education should focus on theoretical knowledge which involves three aspects of subject-matter courses, education-related courses and methods courses, and practical activities which involve four aspects of teaching practice, teaching reflection, and teamwork as these aspects had a positive effect on practical knowledge acquisition. Similarly, Jie (2016) also believed that practical knowledge acquisition of pre-service teachers should be linked to theoretical knowledge and practical activities. Based on this conceptual framework, Jie investigated various factors affecting practical knowledge acquisition of pre-service teachers in practicum, and found that five factors have a strong influence on practical knowledge, including (a) subject matter knowledge learning, (b) teaching practice, (c) the guidance of experienced teachers, (d) feedback of colleagues and students (d) teaching reflection.

Although acknowledging the rationality of this framework, the researchers realized that one factor might be missing in the framework. It is the factor of instructional design. Instructional design is an unfamiliar journey that treats design as a dual learning process (innovation and maintenance learning) and describes designers as learners (Yanchar, 2016). More fundamentally, the nature of design per se as an aspect of educational practice, particularly with regard to computer-based instruction (Bichelmeyer, Boling, \& Gibbons, 2006). Especially for the practicum of pre-service teachers, teaching design can improve their flexibility, adaptability and the ability of creative problem-solving, as well as help teachers to obtain practical knowledge (Yanchar, 2016). In summary, refer to the previous studies on computer science teachers education as well as a conceptual framework about the pedagogy of computer science, the researchers determine five possible factors affecting practical knowledge acquisition of pre-service teachers in their practicum as follows: (a) knowledge preparation, referring to the teacher's knowledge storage in the previous educational course; (b) teamwork, referring to pre-service teachers' collective learning, collective practice and collective reflection in the process of practicum; (c) instructional design, referring to the educational practice of systematical design that consists broadly of course-related factors (subject matter knowledge, objectives and learner characteristics), teaching tools and pedagogy; (d) teaching practice, referring to the implementation of pre-service teachers' instructional design in school educational context; and (e)teaching reflection, referring to the process of teachers' self-observation and self-evaluation of teaching. These five possible factors, together with the above-mentioned six components of teachers' practical knowledge, constituted the theoretical framework of this study. 


\section{Method}

In this section, the method of this study is presented in three parts of participants, research instrument and data analysis, respectively.

\subsection{Participants}

This study conducted a rigorous ethical review at the University of Guizhou province before collecting the data. All participating universities had signed consent forms to complete the questionnaire. Participants in this study involved all pre-service computer science teachers in the Guizhou province of China, which comprise of eight normal universities. There are two main reasons why these universities were chosen. On the one hand, these universities pay significant attention to pre-service computer science teachers' practicum, especially in their practical knowledge acquisition. On the other hand, these pre-service teachers get knowledge of computer science and have three times practicums. To achieve this goal, a contact person, usually the director of the educational technology department, was entrusted with distributing the questionnaire at his/her university. A total of 219 questionnaires were received from eight normal universities. The participants were pre-service computer science teachers who were in their sixth semester, 56 males, 163 females with an average age between 18 and 22 years old.

\subsection{Research instrument}

The questionnaire employed in this study was based on the six components of practical knowledge and five possible factors in the computer science practicum of pre-service teachers. For the six components of practical knowledge, the researchers referred to the information technology teachers' practical knowledge questionnaire developed by Yubin et al. (2011), which based on Chen's theoretical model of practical knowledge components. In the compiling process of the five possible factors section, the researcher referred to the effect of pre-service teachers' practicum questionnaire developed by Jie (2016). Besides, the researchers had consulted six experts on computer science teachers' education for their comments on the six components and five factors of practical knowledge and had asked seventeen of pre-service computer science teachers in Guizhou province of China to participate in a pilot study. The pilot study helped researchers correct the expression and representation of items in the questionnaire. The questionnaire consisted of 32 questions. Questions 1-3 are intended to provide background information on the age, gender and experience of pre-service teachers. Questions 4-27 focus on the six components of practical knowledge acquisition. Specifically, practical knowledge acquisition comprises educational belief, self-knowledge, situational knowledge, interpersonal relationship knowledge, teaching strategies knowledge, and self-reflection knowledge.

Questions 28-32 focus on the five factors in the pre-service teachers' practicum. Specifically, the five factors include knowledge preparation (subject matter knowledge, educational theories knowledge and pedagogy knowledge), teamwork (collective learning, collective practice and collective reflection), instruc- 
tional design (students learning needs, instructional strategies design and selection of teaching tools and materials), teaching practice (adjust the instructional design flexibly, interaction with students, face the challenge positively), and teaching reflection (reflection on teaching methods, instructional design, educational theory and teaching practice). The statement of questions4-32in this study was attached in Appendix 1. The questionnaire used the 5-point Likert from 1 (strongly disagree) to 5 (strongly agreed). The overall Cronbach's alpha value is $0.840(>.70)$. In this study, 219 questionnaires were distributed and 219 valid questionnaires were collected.

\subsection{Data analysis}

The data collected by the questionnaire were processed in-depth using the statistical software package for the SPSS 25 edition. To determine the relationship between the five factors in practicum (independent variables) and six components of practical knowledge acquisition (dependent variables), multiple regression analysis was conducted. Specifically, the objectives of this study were to identify: (1) the relationship between the five factors and educational beliefs acquisition; (2) the relationship between the five factors and self-knowledge acquisition; (3) the relationship between the five factors and situational knowledge acquisition; (4) the relationship between the five factors and interpersonal relationship knowledge acquisition; (5) the relationship between the five factors and teaching strategies knowledge acquisition; and (6) the relationship between the five factors and self-reflection knowledge acquisition.

\section{Results and Discussion}

In order to achieve the research objectives, multiple regression analysis was run to predict each component of practical knowledge acquisition with the five factors in practicum. Table 1 shows the results of the regression analysis. The research results are presented in the order of research objectives, respectively mentioned as follows:

Objective 1 : As show in the table 1, the multiple regression model statistically significantly predicted educational beliefs acquisition, $F=11.959, p=0.0009$, adj. $\mathrm{R}^{2}=.457$. The result indicates that knowledge preparation has predicting function on educational beliefs acquisition of pre-service computer science teachers in their practicum $(\mathrm{p}<.05)$.

Based on the result, it can be concluded that knowledge preparation plays an important role in the educational beliefs of pre-service computer science teachers. In the literature, teachers' knowledge is associated with educational beliefs. According to Pajares (1992), educational belief is a part of practical knowledge which is closely interwoven with knowledge. Pre-service teachers' beliefs are also influenced by their personal biographies, such as knowledge and disciplinary background, their own teachers and their own students (Driel, Beijaard, \& Verloop, 2001). Although the practicum of pre-service teachers may cause some changes in educational beliefs, the change might not be enough to affect the way these pre-service teachers teach if their educational beliefs are persistent (Swafford, 1995; Armoni, 2011). A probable explanation of this study finding is that knowledge preparation of computer science education, which is an important 
aspect of pre-service teachers' practicum in university, is enough to affect their beliefs. It is further supported by the research conducted by Cooney \& Wiegel (2003), which states that pre-service teachers' educational beliefs are mostly affected by the knowledge and the way they were taught as students at school or university. Hence, pre-service teachers who have sufficient knowledge preparation in the computer science education field will significantly influence their educational belief and confidence to teach computer science to children.

Table 1: Results of multiple regression analysis

\begin{tabular}{|c|c|c|c|c|c|c|}
\hline $\begin{array}{l}\text { Ob- } \\
\text { jec- } \\
\text { tive }\end{array}$ & $\begin{array}{l}\text { Dependent } \\
\text { variables }\end{array}$ & Model & $\begin{array}{l}\text { Non-standardized } \\
\text { coefficients }\end{array}$ & $\begin{array}{c}\text { Standardized } \\
\text { coefficients }\end{array}$ & $T$ & Sig. \\
\hline 1 & $\begin{array}{l}\text { Educational beliefs } \\
\text { acquisition }\end{array}$ & $\begin{array}{l}\text { Knowledge } \\
\text { preparation }\end{array}$ & 0.216 & 0.214 & 2.667 & 0.009 \\
\hline \multirow[t]{3}{*}{2} & \multirow[t]{3}{*}{$\begin{array}{l}\text { Self-knowledge } \\
\text { acquisition }\end{array}$} & $\begin{array}{l}\text { Knowledge } \\
\text { preparation }\end{array}$ & 0.335 & 0.387 & 5.028 & 0.000 \\
\hline & & $\begin{array}{c}\text { Instructional } \\
\text { design }\end{array}$ & -0.192 & -0.204 & -2.199 & 0.029 \\
\hline & & $\begin{array}{l}\text { Teaching } \\
\text { reflection }\end{array}$ & 0.90 & 0.219 & 2.541 & 0.001 \\
\hline \multirow[t]{3}{*}{3} & \multirow{3}{*}{$\begin{array}{c}\text { Situational } \\
\text { knowledge acquisi- } \\
\text { tion }\end{array}$} & $\begin{array}{l}\text { Knowledge } \\
\text { preparation }\end{array}$ & 0.110 & 0.223 & 2.678 & 0.008 \\
\hline & & Teamwork & 0.118 & 0.187 & 2.164 & 0.032 \\
\hline & & $\begin{array}{l}\text { Teaching } \\
\text { reflection }\end{array}$ & -0.120 & -0.276 & -3.249 & 0.001 \\
\hline \multirow[t]{2}{*}{4} & \multirow{2}{*}{$\begin{array}{l}\text { Interpersonal rela- } \\
\text { tionship knowledge } \\
\text { acquisition }\end{array}$} & $\begin{array}{l}\text { Teaching } \\
\text { practice }\end{array}$ & -0.175 & -0.291 & -3.236 & 0.001 \\
\hline & & $\begin{array}{l}\text { Knowledge } \\
\text { preparation }\end{array}$ & 0.129 & 0.239 & -2.657 & 0.009 \\
\hline \multirow[t]{4}{*}{5} & \multirow{4}{*}{$\begin{array}{l}\text { Teaching strategies } \\
\text { knowledge acquisi- } \\
\text { tion }\end{array}$} & $\begin{array}{l}\text { Knowledge } \\
\text { preparation }\end{array}$ & 0.098 & 0.137 & 1.762 & 0.008 \\
\hline & & $\begin{array}{l}\text { Teaching } \\
\text { practice }\end{array}$ & 0.119 & 0.264 & 2.966 & 0.004 \\
\hline & & $\begin{array}{l}\text { Instructional } \\
\text { design }\end{array}$ & -0.154 & -0.191 & -1.915 & 0.007 \\
\hline & & $\begin{array}{l}\text { Teaching } \\
\text { reflection }\end{array}$ & 0.120 & 0.188 & 2.040 & 0.043 \\
\hline \multirow[t]{2}{*}{6} & \multirow{2}{*}{$\begin{array}{l}\text { Self-reflection } \\
\text { knowledge acquisi- } \\
\text { tion }\end{array}$} & Teamwork & 0.260 & 0.179 & 2.286 & 0.024 \\
\hline & & $\begin{array}{l}\text { Instructional } \\
\text { design }\end{array}$ & 0.538 & 0.427 & 5.459 & 0.000 \\
\hline
\end{tabular}


Objective 2 : The multiple regression model statistically significantly predicted self-knowledge acquisition, $\mathrm{F}=6.453, \mathrm{p}<.001$, adj. $\mathrm{R}^{2}=.117$. The result indicates that three factors of knowledge preparation, teaching reflection and instructional design have predicting function on self-knowledge acquisition $(\mathrm{p}<.05)$, and the factors of knowledge preparation had a greater effect.

Teacher's self-knowledge is a crucial element of teachers' practical knowledge acquisition with their practicum, due to good teaching ultimately emerges from the inner landscapes of teachers, that is, we teach who we are (Palmer, 1997). Many studies have proved that teaching reflection is perceived by teachers to be most important to the acquisition of self-knowledge (Sedikides, \& Skowronski, 1995; MacLellan, 2012; Stenberg, 2011). Teaching reflection as a meaning-making process and self-explanatory process on teaching practice serve the way to produce self-knowledge and making pre-service computer science teachers monitor their own behavior and take appropriate action at a conscious and rational level. However, in the context of this study, the most important factor affecting self-knowledge acquisition is knowledge preparation, followed by teaching reflection and instructional design. Lifang (2014) also achieves similar results by using the quantitative method, which found that knowledge preparation (knowledge about subject-matter, education-related and teaching methods) is the foundation of self-knowledge construction. This may be due to the fact that the dual identity of pre-service teachers (learners and educators) makes the construction of their self-knowledge dependent on their knowledge learning and course experience. For instructional design, in the context of constructivism, instructional design as a kind of dialogue based on individual meaning, promote pre-service teachers extending their self-knowledge through the way of their self-reflection on maintenance learning (familiar and apply extant knowledge, experience and tools into the instructional design ) and innovative learning (involves both major and minor excursions into the unfamiliar situation) in the instructional design process (Yanchar, 2016; Reigeluth, \& Moore, 1999).

Objective 3 : The multiple regression model statistically significantly predicted situational knowledge acquisition, $\mathrm{F}=6.453, \mathrm{p}<.001$, adj. $\mathrm{R}^{2}=.117$. The result indicates that three factors of knowledge preparation, teamwork and teaching reflection have predicting function on situational knowledge acquisition $(p<.05)$, and the factors of teaching reflection had a greater effect.

In the practicum of pre-service teachers, situational knowledge or context knowledge can be observed when a pre-service teacher knows, does, and feels every minute in their everyday classroom life. Barnett \& Wiegel (2001) found that situational knowledge can be affected by internal and external factors. Internal factors include teaching reflection and personal experiences, whereas external factors include subject matter knowledge, exchange with other teachers, governmental regulation and school policies. Similarly, this study found that both internal (teaching reflection) and external (knowledge preparation and teamwork) factors had contributed to the increase of situational knowledge acquisition of pre-service computer science teachers in practicum. 
Objective 4 : The multiple regression model statistically significantly predicted interpersonal relationship knowledge acquisition, $\mathrm{F}=6.065, \mathrm{p}=.003$, adj. $R^{2}=.306$. The result indicates that these two factors of teaching practice and knowledge preparation have predicting function on interpersonal relationship knowledge acquisition $(\mathrm{p}<.05)$, and the factor of teaching practice had a greater effect.

These findings are understandable in terms of the nature of interpersonal relationship knowledge, which involves understanding of students, enthusiasm and passion (Chen, 2019). Pre-service teachers engaged in teaching practice were mostly interested in learning about the educational activities in the computer science classroom (Montecinos et al. 2011). Moreover, pre-service teachers in practicum engaged in computer science teaching practice, eager to meet the positive interpersonal enthusiasm and passion for psychological needs (Evelein, Korthagen, \& Brekelmans, 2008). Hence, interpersonal relationship knowledge in the setting of computer science practicum can be perceived by the teaching practice of pre-service teachers. Moreover, the acquisition of pre-service teachers' interpersonal relationship knowledge is significantly influenced by their knowledge preparation, which enables pre-service teachers to develop positive interpersonal relationships with university mentors and their students. Fundamentally, whether pre-service teachers have sufficient knowledge directly determines the quality of knowledge sharing and communication in the process of computer science practicum. In other words, pre-service teachers' insufficient knowledge reduces the quality of knowledge sharing and communication, and thus the low reciprocity of knowledge in interpersonal relationships may make pre-service teachers hard to acquire interpersonal relationship knowledge (Gainforth, 2014). This is why teaching practice and knowledge preparation in the practicum of pre-service teachers could predict the interpersonal relationship knowledge acquisition.

Objective 5 : The multiple regression model statistically significantly predicted teaching strategies knowledge acquisition, $F=4.517, \mathrm{p}=.005$, adj. $\mathrm{R}^{2}=.319$. The result indicates that these four factors of knowledge preparation, teaching practice, instructional design and teaching reflection have predicting function on teaching strategies knowledge acquisition $(\mathrm{p}<.05)$, and knowledge preparation had a greater effect.

Similar to a study by Jie (2016), who suggested that teaching strategies knowledge are influenced by three factors of knowledge preparation, teaching practice and teaching reflection. The knowledge possessed by pre-service teachers can influence their teaching strategy choice. That is to say, the teaching strategies adopted by the pre-service teachers in practicum are mainly derived from the previous computer science education curriculum, which contains much practical work, because the pre-service teachers are not rich in practical experience, can not skilfully master teaching strategies and innovative use in practicum. Moreover, the teaching practice makes pre-service teachers reflect on the teaching strategies which pre-service teachers willing to use in their practicum. Through the teaching reflection, pre-service teachers can transform the 
knowledge of teaching strategies from the academic courses into their own knowledge, which is more individuation and practicality. Besides the three factors mentioned, this study found a new factor, which is the instructional design that would have a significant influence on teaching strategies acquisition. When pre-service teachers conducted their own instructional design as well as discussed with their peers, they were stimulated to develop their own teaching strategies knowledge (Geddis, 1993; Van Driel et al., 1998). This is why knowledge preparation, teaching practice, instructional design and teaching reflection factors in the practicum of pre-service teachers could predict the teaching strategies knowledge acquisition.

Objective 6 : The multiple regression model statistically significantly predicted self-reflection knowledge acquisition, $\mathrm{F}=29.11, \mathrm{p}<.001$, adj. $\mathrm{R}^{2}=.284$. The result indicates that two factors of instructional design and teamwork have predicting function on self-reflection acquisition $(p<.05)$, and instructional design had a greater effect.

Although pre-service teachers in the process of instructional design mainly rely on the existing mature teaching plan and pay attention to the design process without making mistakes, the process of pre-service teachers thinking about the scientificity and rationality of instructional design includes their reflection on self-knowledge and experience. As Smith \& Ragan (1999) claim, in essence, instructional design is a reflective process in which the principles of education are translated into educational activities. For the teamwork factor, Foong, Binti \& Nolan (2018), who investigated the relationship between individual and collective reflection, found that collective reflection supported higher levels of individual reflective thinking during practicum. The possible explanation for this might be teamwork allows pre-service teachers to exchange their experience and idea to the other team member as well as get feedback from others. Hence, the factors of the above perspectives explain why the factors of instructional design and teamwork in the practicum of pre-service teachers could predict the self-reflection acquisition, and further help they understand why teachers and students do in the computer science classroom.

\section{Conclusion}

Overall, this study aimed to address the issue of which factor in the practicum of pre-service computer science teachers can predict the acquisition of each component of practical knowledge, and its main findings suggested that the factors influencing each component of practical knowledge are very different. From the results of this study, the factor of knowledge preparation significantly predicted the acquisition of educational beliefs, self-knowledge, situational knowledge, interpersonal relationship knowledge and teaching strategies knowledge in the practicum. This meaning that pre-service computer science teachers' knowledge preparation is very useful for their practical knowledge acquisition. Some scholars indicated that educational knowledge from university courses have a minor influence on their practical knowledge acquisition, due to the practicality of educational knowledge is very low (Tsai, \& Liu, 2013; Deed, Cox, \& Prain, 2011). However, in the setting of computer science education, knowledge preparation 
or university courses involve much practical work and hands-on activities, which have strong practicality in the practicum, and enhance pre-service teachers acquire practical knowledge. Moreover, it must be noted that unlike the servicing teachers, pre-service teachers are still at the stage of learning and accumulating knowledge. If the pre-service teacher is not well prepared, they are likely to experience failure in practicum; thus, losing motivation and confidence to become computer science teachers.

As for the factors of teaching reflection and instructional design, teaching reflection significantly predicted the acquisition of self-knowledge, situational knowledge, and teaching strategies knowledge in the practicum, while instructional design significantly predicted the acquisition of self-knowledge, teaching strategies knowledge and self-reflection knowledge. Teaching reflection would be an essential tool for the pre-service teacher education as it is considered as a meta-cognitive and a characteristic of higher-order thinking, which enable pre-service teachers to examine their own educational knowledge, thoughts, attitudes and actions (Cooney, 2003). Meanwhile, as mentioned above, instructional design as a way of pre-service teacher's reflection can help teachers organize their educational knowledge systematically in the design, which meets the needs of students, and considers and reviews the feasibility and effectiveness of teaching design. Obviously, teaching reflection and instructional design as two essential factors enhance the acquisition of pre-service teachers' practical knowledge by observing their own actions and introspecting their own attitudes, beliefs, and understandings in the practicum.

Moreover, teaching practice significantly predicted the acquisition of interpersonal relationship knowledge and teaching strategies knowledge. As a possible explanation, this could be the result of the fact that the teaching practice of pre-service teachers in the practicum strengthens the relations between theory and practice, pre-service teachers and students, the method curriculum and the actual situation (Hazzan \& Lapidot, 2004). Finally, the factor of teamwork significantly predicted the acquisition of situational knowledge and self-reflection knowledge. In this study, teamwork in the situation of computer science education where a group is working together to achieve a common goal through analysis and adapt to the specific situation of the classroom, and collective reflection, and thus enhance the practical knowledge acquisition.

In conclusion, this study suggested that the education of pre-service computer science teachers for practical knowledge acquisition should focus on the integration of theoretical knowledge and practical knowledge with considering the effects of the five factors. From this study, under the conceptual framework proposed by Armoni (2011) and Jie (2016), we have come to understand that the five factors in the process of practicum of pre-service computer science teachers do not exist in isolation. Instead, these factors are closely related to each other as they influence one another.

There are some limitations in this study. Although Chinese government departments have established regulations and guidelines for pre-service teacher 
education to regulate the activities of normal universities in implementing pre-service teacher education, each university in different provinces of China can still implement different techniques for equipping pre-service teachers with abilities, especially in the practicum of computer science teachers. This study only took Guizhou province as the sample. Therefore, it cannot be generalized to all Chinese pre-service computer science teacher education. Hence, it is recommended for future research that focuses on comparing the impact of different practicum module on practical knowledge acquisition among pre-service computer science teachers in different provinces.

\section{Funding Statement}

Financial support was granted by the Faculty of Educational Studies, Universiti Putra Malaysia, as well as by the "13th Five-Year Plan" of Chinese Educational Science, the unit funded the planning project of the ministry of education in 2017, [No. FFB170631].

\section{References}

Adehfez, A. (2010). An Investigation into Professional Practical Knowledge of EFL Experienced Teachers in Egypt: Implications for Pre-service and In-service Teacher Learning (PhDthesis).University of Exeter.

Abrahams, I., \& Millar, R. (2008). Does practical work really work? A study of the effectiveness of practical work as a teaching and learning method in school science. International Journal of Science Education, 30, 1945-1969. doi:10.1080/09500690701749305

Armoni, M. (2011). Looking at Secondary Teacher Preparation Through the Lens of Computer Science. ACM Transactions on Computing Education, 11(4), 1-38. doi:10.1145/2048931.2048934

Barnett, J., \& Hodson, D. (2001). Pedagogical context knowledge: Toward a fuller understanding of what good science teachers know. Science Education, 85(4), 426-453. doi:10.1002/sce.1017

Ben-Peretz, M. (2011). Teacher knowledge: what is it? how do we uncover it? what are its implications for schooling?. Teaching and Teacher Education, 27(1), 1-9. doi:10.1016/j.tate.2010.07.015

Bichelmeyer, B., Boling, E., \& Gibbons, A. S. (2006). Instructional design and technology models: Their impact on research and teaching in instructional design and technology. In M. Orey, V. J. McClendon, \& R. M . Branch (Eds.), Educational media and technology yearbook (Vol. 31, pp. 33- 73). Littleton, CO: Libraries Unlimited.

Britzman, D. P.(2003). Practice makes practice: A critical study oflearning to teach. Albany: State University of New York Press. Original work published 1990.

Carter, K. (1990). Teachers knowledge and learning to teach. In W. R. Houston (Ed.), Handbook of research on teacher education (pp. 219-310). New York: Macmillan.

Chen, X. M. (2019). A reexamination of teachers 'practical knowledge: Responses to some questions. Peking University Education Review, 16(4), 3-9. (in Chinese)

Chen, X. M. (2003). Practical knowledge: the knowledge base of teacher professional development. Education review of Peking University (01), 106-114. (in Chinese).

Chittleborough, G. D., Clarke, J. C., \& Hubber, P. (2010). Pre-service teachers' practicum experiences: developing pedagogy and professional skills through relationships with supervising teachers, coordinating teachers and university staff. Australian Association for Research in Education Conference.

Cooney, T. J., \& Wiegel, H. G. (2003). Examining the Mathematics in Mathematics Teacher 
Education. Second International Handbook of Mathematics Education, 795-828. doi:10.1007/978-94-010-0273-8_26

Deed, C., Cox, P., \& Prain, V. (2011). Enablers and constraints in achieving integration in a teacher preparation program. Australian Journal of Teacher Education, 36(8), 1-92. doi:10.14221/ajte.2011v36n8.3

Driel, J. H. V., Beijaard, D., \& Verloop, N. (2001). Professional development and reform in science education: the role of teachers' practical knowledge. Journal of Research in Science Teaching, 38(2), 137-158. doi:10.1080/1046560X.2016.1277599

Elbaz, F. (1981). The teacher's practical knowledge: Report of a case study. Curriculum Inquiry, 11(1), 44-71.

Evelein, F., Korthagen, F., \& Brekelmans, M. (2008). Fulfillment of the basic psychological needs of student teachers during their first teaching experiences. Teaching and Teacher Education, 24, 1137-1148. doi:10.1016/j.tate.2007.09.001

Fan, L. (2014). Investigating the pedagogy of mathematics: How do teachers develop their knowledge. London: Imperial College Press.

Foong, L., Binti, M., \& Nolan, A. (2018). Individual and Collective Reflection: Deepening Early Childhood Pre-service Teachers' Reflective Thinking during Practicum. Australasian Journal of Early Childhood, 43(1), 43-51. doi:10.23965/ajec.43.1.05

Gainforth, H. L., Latimer-Cheung, A. E., Athanasopoulos, P., Moore, S., \& Ginis, K. A. M. (2014). The role of interpersonal communication in the process of knowledge mobilization within a community-based organization: a network analysis. Implementation Science, 9(1), 2-8. doi:10.1186/1748-5908-9-59

Geddis, A. N. (1993). Transforming subject-matter knowledge: The role of pedagogical content knowledge in learning to react on teaching. International Journal of Science Education, 15, 673-683. doi:10.1080/0950069930150605

Gronn, D., Romeo, G., Mcnamara, S., \& Teo, Y. H. (2013). Web conferencing of pre-service teachers' practicum in remote schools. Journal of Technology $\mathcal{E}$ Teacher Education, 21, 247-271.

Hazzan, O., \& Lapidot, T., (2004). The practicum in computer science education: bridging gaps between theoretical knowledge and actual performance. ACM SIGCSE Bulletin, 36, 47-51. doi:10.1145/1041624.1041655

Jaworski, B., \& Gellert, U. (2003). Educating New Mathematics Teachers: Integrating Theory and Practice, and the Roles of Practisin Teachers. Second International Handbook of Mathematics Education, 829-875. doi:10.1007/978-94-010-0273-8_27

Jie, D. (2016). A study of novice teacher's practical knowledge acquisition. (Doctoral dissertation) (in Chinese).

Kauchak, D. P., \& Eggen, P. D. (2003). Learning and teaching. Fourth edition. Boston: Pearson Education.

Lee, G. C., \& Chang, L. C. (2000). Evaluating the effectiveness of a network-based subject knowledge guidance model for computer science student teachers. Asia-Pacific Journal of Teacher Education \& Development, 3(1), 187-209.

Li, Y., Yang, X., Nan L., \& Hou L. (2011). Analysis on the current situation and influencing factors of it teachers 'practical knowledge. Audio-visual education in China 12, 66-70. (in Chinese).

Li, L. (2015). A study on the cultivation of practical knowledge of normal school students based on the narrative of primary education students. Education Development Research 4, 48-53. (in Chinese).

MacLellan, E. (2012) Teaching mathematics: self-knowledge, pupil knowledge and content knowledge. In: Improving Primary Mathematics Teaching and Learning. The Open University Press, pp. 213-228. ISBN 9780335246. 
Meijer, P. C., Verloop, N., \& Beijaard, D. (1999). Exploring language teachers practical knowledge about teaching reading comprehension. Teaching and Teacher Education, 13, 59-84. doi:10.1016/S0742-051X(98)00045-6

Montecinos, C., Walker, H., Rittershaussen, S., Nunez, C., Contreras, I., \& Solis, M. (2011). Defining content for field-based coursework:Contrasting the perspectives of secondary pre-service teachers and their teacher preparation curricula. Teaching and Teacher Education, 27(2), 278-288. doi:10.1016/j.tate.2010.09.001

Ni, X. (2010). Practice Orientation: Reconstruction of pre-service Teacher Education Model. Teacher Education Research, 221, 22-27. (in Chinese)

Ofra, B., \& Michal, A. (2019). Using action research to distill research-based segments of pedagogical content knowledge of K-12 computer science teachers. In Proceedings of the 24th Annual Conference on Innovation and Technology in Computer Science Education, 485-491. doi:10.1145/3304221.3319773

Oonk, W., Verloop, N., \& Gravemeijer, K. (2015). Enriching practical knowledge: exploring student teachers' competence in integrating theory and practice of mathematics teaching. Journal for Research in Mathematics Education, 46(5), 560-563. doi:10.5951/jresematheduc.46.5.0559

Orit, H., \& Tami, L. (2004). The practicum in computer science education: bridging gaps between theoretical knowledge and actual performance. ACM SIGCSE Bulletin, 36, 47-51. doi:10.1145/1041624.1041655

Oss, D. I. B. (2018). The relevance of teachers' practical knowledge in the development of teacher education programs. Profile Issues in Teachers Professional Development, 20(1), 167-178. doi:10.15446/profile.v20n1.62327

Palmer, P. (1997). The heart of a teacher. Identity and integrity in teaching. Change Magazine, 29(6), 14-21. doi:10.1080/00091389709602343

Pan, L., (2014). An investigation of teachers' practical knowledge formation: A case study of Shanghai Primary School Teachers. Open Education Research, 202, 80-87. (in Chinese)

Pietig, J. (1997). Foundations and teacher education: Do we need a new metaphor? J. Teach. Educ. 48, 3, 177-184. doi:10.1177/0022487197048003003

Ragonis, N., \& Oster-Levinz, A. . (2011). Pre-service Computer Science Teacher Training within the Professional Development School (PDS) Collaboration Framework. Informatics in Schools Contributing to Century Education-international Conference on Informatics in Schools: Situation. Springer Berlin Heidelberg. doi:10.1007/978-3-642-24722-4_10

Sedikides, C., \& Skowronski, J. J. (1995). On the sources of self-knowledge: The perceived primacy of self-reflection. Journal of Social and Clinical Psychology, 14(3), 244-270. doi:10.1521/jscp.1995.14.3.244

Shulman, L. (1987). Knowledge and Teaching: Foundations of the New Reform. Harvard Educational Review, 57(1), 1-23. doi:10.17763/haer.57.1.j463w79r56455411

Smith, P. L., \& Ragan, T. J. (1999). Instructional design (2nd ed.). Upper Saddle River, NJ: Prentice Hall.

Stenberg, K. (2011). Working with identities -promoting student teachers' professional development. Helsinki: University of Helsinki, Faculty of Behavioural Sciences.

Swafford, J. O. (1995). Teacher preparation. In Prospects for School Mathematics, I. M. Carl Ed., National Council of Teachers of Mathematics, Reston, VA, 157-174.

Tsai, H.-C., \& Liu, S.-H. (2013). The Practical Source of Educational Knowledge for Pre-Service Teachers in Confronting Field-Based Challenges in School Practicum. Higher Education Studies, 3(4). doi:10.5539/hes.v3n4p67

Van Driel, J. H., Verloop, N., \& De Vos, W. (1998). Developing science teachers' pedagogical content knowledge. Journal of Research in Science Teaching, 35, 673-695. 
Von Hausswolff, K. (2017). Hands-on in Computer Programming Education. Proceedings of the 2017 ACM Conference on International Computing Education Research- ICER17. doi:10.1145/3105726.310573

Yanchar, S. C. (2016). Instructional design Practice as Innovative Learning: Journeys into the Unfamiliar. Educational Technology, 56(1), 14-21.

Zanting, A., Verloop, N., \& Vermunt, J. D. (2001). Student teachers eliciting mentors' practical knowledge and comparing it to their own beliefs. Teaching $\mathcal{E}$ Teacher Education, 17(6), 725-740. doi:10.1016/S0742-051X(01)00026-9

\section{Appendix 1}

The statement of questions 4-32 of the instrument

NO. Item Statement

Educational beliefs

$4 \quad$ I understand the purpose of computer science education and work hard to achieve it.

5 I should adjust my teaching method to the classroom situation.

6 I think all students should be educated in computer science.

$7 \quad$ I believe I can overcome the difficulties in teaching

Self-knowledge

$8 \quad$ I understand my own character.

9 I can learn from mistakes and adjust my own attitude and behavior.

10

I am willing to accept the feedback from students and other teachers

11

I understand my own teaching ability

Situational knowledge

12 I can use educational opportunities reasonably.

13 I can adapt to the new environment.

14 I can handle the problems in classroom teaching

15 I can use theoretical knowledgeflexibly in classroom teaching.

Interpersonal relationship knowledge

16 I can communicate well with students

17 I am willing to help students.

18 I am willing to learn new knowledge and teach them to students in the area of computer science. 
19 I can communicate well with other teachers

Teaching strategies knowledge

20 I can use teaching methods flexibly.

21 I can present the teaching content in an appropriate manner.

22 I can solve students' problems in their studies.

23 I can use multiple strategies to organize my teaching procedure.

Self-reflection knowledge

24 I can reflect in action.

25 I often use reflective methods in my practicum.

26 I often reflect on my own professional growth

27

I think self-reflection is very important for my growth.

How much did the following factors contribute to your practical knowledge acquisition during practicum

$28 \quad$ Knowledge preparation

29 Teamwork

$30 \quad$ Instructional design

$31 \quad$ Teaching practice

$32 \quad$ Teaching reflection 